\title{
Ultrastructural Classification of Pituitary Adenomas
}

\author{
E. HORVATH, and K. KOVACS.
}

SUMMARY: Forty-eight surgically removed pituitary adenomas have been investigated by electron microscopy. Distinct differences in fine structural appearances permitted their separation into 5 classes: 1) Growth hormone, (GH)-cell tumors; 2) Prolactin cell tumors; 3) Mixed adenomas composed of $\mathrm{GH}$ and prolactin cells; 4) Adrenocorticotrophic-Melanocyte stimulating hormone ( $A C T H-M S H)$ cell tumors; 5) Undifferentiated cell adenomas. Densely and sparsely granulated tumors were distinguished within

RÉSUMÉ: 48 adénomes pituitaires enlevés par chirurgie ont été examinés au microscope électronique. Des différences distinctes de structure ont permis une classification en 5 groupes: 1) tumeurs à cellules "Hormone de croissance" (HC); 2) tumeurs à cellules-prolactine; 3) Adénomes mixtes composés de cellules $H C$ et à prolactine; 4) tumeurs à ACTH/MSH; 5) Adénomes à cellules non différenciées. Des tumeurs densément granulées ou peu abondantes furent observées dans les groupes 1, 2 et 4. De plus, quoique ces deux formes classes 1, 2 and 4. Although these two forms appeared to represent well defined entities, they may be variants of the same tumor differing only in pace of hormone production andlor release. Number and size of secretory granules varied considerably among tumors composed of the same cell type indicating that pituitary tumor classification cannot be based solely on granule morphology. This classification takes into account morphogenesis with emphasis on clinical features and structure-function relationship.

semblent représenter des entités bien définies, elles pourraient être des variantes de la même tumeur différant seulement dans la vitesse de production de l'hormone etlou sa libération. Le nombre et la dimension des granules sécrétrices varie considérablement chez les tumeurs de même type, indiquant que la classification des tumeurs pituitaires ne peut être basée uniquement sur la morphologie des granules. Cette classification prend en considération la morpho- génèse, les faits cliniques et la relation structure-fonction.
From the Department of Pathology, St. Michael's Hospital and University of Toronto, Toronto, Ontario, Canada

Reprint requests to Dr. E. Horvath, Department of Pathology, St. Michael's Hospital, 30 Bond Street, Toronto, Ontario M5B IW8 Canada.

\section{INTRODUCTION \\ "Ordo est anima rerum."}

About $50 \%$ of pituitary adenomas are "chromophobe", i. e. they do not exhibit well defined tinctorial properties by light microscopy which would serve as a basis for their histologic diagnosis. Even if a few small secretory granules can be detected in the tumor cell cytoplasm by using special staining methods (McCormick and Halmi, 1971) this does not allow for their identification. Thus, in a large number of pituitary tumors the cell type from which they arise cannot be identified. By electron microscopy certain fine structural differences have been detected among various chromophobe adenomas by several investigators (Schelin, 1962; Kuromatsu, 1968; Zambrano et al ., 1968; Schechter, 1973a; Tomiyasu et al., 1973; Lewis and Van Noorden, 1974). These studies, however, failed to result in a satisfactory classification of chromophobe tumors by light microscopy. In recent years a few workers have dealt with the ultrastructural cytology of adenohypophysial adenomas on a broader basis (Mosca and Vassallo, 1970; Foncin, 1971; Pelletier, 1971; Doniach, 1972). No attempts were made, however, to establish a classification of pituitary adenomas by clearly defined fine structural features and to assign them to distinct cell types for diagnostic purposes.

On the basis of detailed light and electron microscopic investigations of 48 adenomas and the correlation between structure, clinical history and hormone determinations, as well as of the study of the pertinent literature, we herewith propose such a classification. Our system is based upon the recognition of two general principles: a) neither the light microscopic agranularity of an adenoma 
TABLE I

CLASSIFICATION OF PITUITARY ADENOMAS

\begin{tabular}{|c|c|c|c|c|}
\hline Adenoma Type & $\begin{array}{l}\text { Tinctorial Properties } \\
\text { by Light Microscopy }\end{array}$ & Clinical Manifestations & $\begin{array}{l}\text { No. in } \\
\text { Present } \\
\text { Material }\end{array}$ & $\begin{array}{c}\text { Incidence } \\
\text { (Per Cent) } \\
\text { in Present } \\
\text { Material }\end{array}$ \\
\hline
\end{tabular}

\begin{tabular}{lllll}
\hline \hline I. & 1. & $\begin{array}{l}\text { Densely granulated } \\
\text { GH-cell adenoma }\end{array}$ & Acidophil & 9 \\
\hline I. & 2. & $\begin{array}{l}\text { Sparsely granulated } \\
\text { GH-cell adenoma with } \\
\text { fibrous bodies }\end{array}$ & $\begin{array}{l}\text { Partly acidophil } \\
\text { or chromophobe }\end{array}$ & Acromegaly \\
\hline
\end{tabular}

\begin{tabular}{lll}
\hline II. I. & $\begin{array}{l}\text { Densely granulated } \\
\text { prolactin-cell adenoma }\end{array}$ & $\begin{array}{l}\text { Acidophil, positive } \\
\text { with erythrosine and } \\
\text { carmoisine }\end{array}$
\end{tabular}

II. 2. Sparsely granulated
prolactin cell adenoma
with misplaced
exocytosis (PAME)

Chromophobe, may be partly positive with erythrosine and carmoisine

\begin{tabular}{|c|c|c|c|c|c|}
\hline III. & $\begin{array}{l}\text { Mixed adenoma } \\
\text { composed of } \mathrm{GH} \text { and } \\
\text { prolactin cells }\end{array}$ & $\begin{array}{l}\text { Any combination of } \\
\text { Groups } 1.1-\text { II. } 2\end{array}$ & $\begin{array}{l}\text { Hyperprolactinemia with } \\
\text { or without acromegaly }\end{array}$ & 4 & 8 \\
\hline IV. 1. & $\begin{array}{l}\text { Densely granulated } \\
\text { ACTH-MSH cell adenoma }\end{array}$ & $\begin{array}{l}\text { Amphophil, PAS- } \\
\text { positive }\end{array}$ & \multirow{2}{*}{$\begin{array}{l}\text { Hypercorticism, hyper- } \\
\text { pigmentation (Cushing's } \\
\text { syndrome), increased blood } \\
\text { ACTH and MSH levels, } \\
\text { hyper-pigmentation } \\
\text { (Nelson's syndrome) }\end{array}$} & 4 & 8 \\
\hline IV. 2. & $\begin{array}{l}\text { Sparsely granulated } \\
\text { ACTH-MSH cell adenoma }\end{array}$ & Not investigated & & - & 一 \\
\hline V. 1. & $\begin{array}{l}\text { Undifferentiated } \\
\text { cell adenoma }\end{array}$ & $\begin{array}{l}\text { Chromophobe or } \\
\text { partly acidophil }\end{array}$ & \multirow{2}{*}{$\begin{array}{l}\text { No known } \\
\text { endocrine } \\
\text { function }\end{array}$} & 9 & 19 \\
\hline V. 2 & Oncocytoma & $\begin{array}{l}\text { Acidophil or } \\
\text { chromophobe }\end{array}$ & & 5 & 10 \\
\hline
\end{tabular}

nor the absence of clinical signs of hormonal hypersecretion necessarily indicate the lack of secretory activity of the tumor; b) various pituitary cell types may give rise to densely as well as sparsely granulated adenomas. The cells of the sparsely granulated variants differ from their densely granulated counterparts not only in the number but also in the size of secretory granules. They may have additional fine structural features, sometimes making it difficult to disclose the cell type from which they derive. The various types of chromophobe adenomas are ultrastructurally distinguishable, not only from the corresponding densely granulated tumor, but from each other as well. Thus, it is almost invariably possible to diagnose and classify them by means of electron microscopy even without clinical and laboratory data.

\section{MATERIALS AND METHODS}

The material which serves as the basis of the present study consists of 48 pituitary adenomas removed by transsphenoidal hypophysectomy. All specimens were fixed rapidly after removal in 2.5 per cent glutaraldehyde in $0.15 \mathrm{M}$ Sorenson's buffer. The tissues were postfixed in 1 per cent $\mathrm{Os}_{4}$ in Millonig's buffer, processed through graded ethanol and propylene oxide and embedded in Epon 812. Sections $0.5 \mu$ thickness were cut with a porter-Blum MT-2 ultramicrotome, stained with toluidine blue and examined by a light microscope to select material for electron microscopic study. The ultrathin sections were stained with uranyl acetate and lead citrate and examined with a Philips 300 electron microscope.

\section{RESULTS}

The proposed tumor classification is shown in Table I. The details will be discussed in order of individual classes.

\section{GROWTH HORMONE CELL ADENOMAS.}

I. I. Densely granulated growth hormone (GH)-cell adenoma (9 cases).

Hypersecretion of $\mathrm{GH}$ is one of the most common pituitary disorders resulting in the characteristic clinical syndrome of acromegaly. In typical cases the diagnosis hardly ever constitutes a problem and the morphology of the adenoma is the most widely studied among hypophyseal neoplasms. In a considerable number of cases acromegaly is associated with a densely granulated acidophil adenoma in which the cytoplasmic granules exhibit bright staining with eosin, phloxine, light green, orange $\mathrm{G}$ or other acid dyes. The electron microscopic features of 
this adenoma are dealt with in several earlier studies (Schelin, 1962; Lewis and Van Noorden, 1972; Robert, 1973; Saeger, 1973a; Schechter, 1973b; Kinnman, 1973), thus, a concise summary will suffice here.

The pure form of densely granulated $\mathrm{GH}$-cell adenoma consists mainly of spherical or oval cells exhibiting uniform fine structural features. The nuclei are round or oval with light chromatin substance; the cytoplasm is relatively lucent. The well developed rough surfaced endoplasmic reticulum (RER) appears as parallel cisternae situated mainly at the periphery of the cytoplasm. Free ribosomes are numerous. Well granulated cells usually possess only a moderate number of oval to rodshaped mitochondria with a medium dense matrix and lamellar or cleftlike cristae. The sacculi of the prominent crescent-shaped Golgi complex may show a slight dilation and regularly contain a few immature secretory granules. In the rest of the cytoplasm the secretory granules are always spherical with a closely apposed limiting membrane and exhibit an even high electron density. Their longest diameter varies between $300-600 \mathrm{~nm}$, the majority of them measuring 350-450 $\mathrm{nm}$ (Fig. I).

Although many acidophil adenomas answer this description, several may contain a varying number of cells possessing less and/or smaller $(100-250 \mathrm{~nm})$ secretory granules. In such cells the shape of the nuclei might be less regular, the RER tends to be more dispersed and dilated and occasionally a fibrous body may appear in the Golgi region. For the sake of simplicity, we classify these tumors as densely granulated GH-cell adenomas, provided that the majority of cells show the ultrastructural characteristics of the densely granulated tumor type.

I. 2. Sparsely granulated $\mathrm{GH}$-cell adenoma with fibrous bodies (7 cases).

By light microscopy, some cases of acromegaly are associated with chromophobe adenoma of the pituitary. These tumors are characterized by the presence of globular fibrous bodies (Schochet et al., 1972;
Kovacs et al., 1974b) which may be detected by using the PAShematoxylin-Orange G-light green technique.

In contrast to densely granulated $\mathrm{GH}$-cell adenomas, the cells of this tumor do not show much similarity to normal GH-cells by electron microscopy. They vary considerably in shape and size. The nuclei are strikingly pleomorphic, many being crescent-shaped with multiple indentations. Large multinuclear cells with eccentrically arranged nuclei are common. In the majority of cells the RER is abundant and is likely to appear in the form of short profiles exhibiting varying degrees of dilation. Cells possessing several parallel arrays of RER, somewhat similar to Nebenkerns, may also occur. Contrary to the cells of the nontumorous pituitary and various other hypophyseal adenomas the cells of sparsely granulated GH-cell tumors contain an appreciable amount of tubular smooth surfaced endoplasmic reticulum (SER), consistently in close association with fibrous bodies. Transition between RER and SER was seen regularly which seems to indicate the RER as the probable source of smooth walled tubules. Free ribosomes and polysomes are present as well. Mitochondrial morphology shows more variation here than in the cells of densely granulated GH-cell adenoma. Most cells contain oval rod-shaped mitochondria with lamellar or cleft-like cristae. Spherulation and swelling, however, also occur, and oncocytic transformation, evident in a variable number of cells in different cases, is not rare in this type. The membrane system of the Golgi apparatus usually is extensively developed taking the shape of a crescent or a flattened ring. The sacculi are mostly flat except for the sites of immature secretory granules. Fibrous bodies frequently interfere with the normal localization of Golgi complex. Parts of the Golgi system may be intermingled with microfilaments, or the Golgi sacculi may encircle the fibrous bodies.

The most distinguishing feature of the sparsely granulated GH-cell

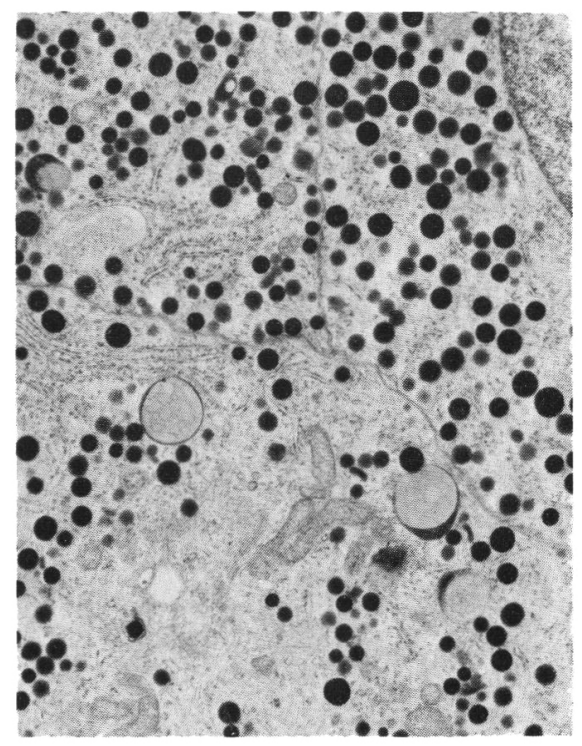

Figure 1-Portions of cells of a densely granulated $\mathrm{GH}$-cell adenoma possessing parallel cisternae of RER, a large number of spherical secretory granules and prominent Golgi apparatus $(x 9,400)$

adenoma is the occurrence of globular fibrous bodies (Fig.2), located near the concave side of the indented or crescent-shaped nucleus and composed of Type II microfilaments with an average width of $115 \mathrm{~A}$

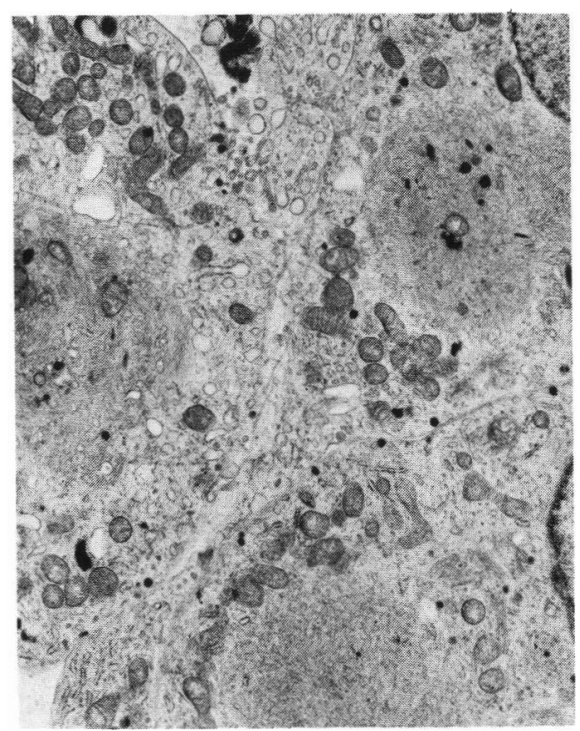

Figure 2-Sparsely granulated GH-cell adenoma with fibrous bodies. The type 11 microfilaments are intermingled with mitochondria, ER profiles and secretory granules. Note the sharply reduced size and number of secretory granules $(x \mathbf{8 , 8 5 0})$ 
(Kovacs et al., 1974b). Cytoplasmic organelles may be intermingled. The incidence of these filamentous aggregates varies from one case to another, but they are usually numerous. They were evident in approximately 10 per cent of the cells in one sparsely granulated GH-cell adenoma; in three others, however, they were present in almost every cell. Another characteristic mark of this tumor type is the frequent occurrence of centrioles (Fig. 3) usually situated near or within the fibrous bodies. A pair of centrioles (with or without a cilium) can be found in numerous cells of the normal or adenomatous human pituitary. However, the puzzling accumulation of 2-3 pairs of centrioles, so commonly seen in sparsely granulated $\mathrm{GH}$-cell adenomas, is unparalleled in other tissues of adenohypophyseal origin. To our knowledge, similar accumulation of centrioles may occur only in some chief cell adenomas of the human parathyroid gland (Polyzonis, 1970). Centrioles and cilia are regular components of embryonic cells and are also known to develop and multiply under certain experimental conditions (Milhaud and Pappas, 1968). We cannot offer any explanation, how-

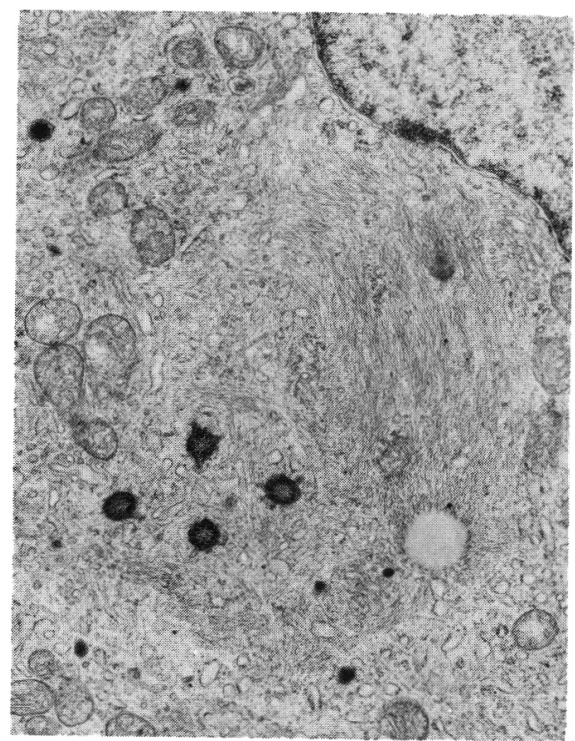

Figure 3-Sparsely granulated GH-cell adenoma with fibrous bodies. Two pairs of centrioles are situated in the Golgi region, encircled by the type II microfilaments of a fibrous body ( $x$ 17,100 . ever, for their increased number in this particular pituitary tumor.

The spherical, dense secretory granules, invariably present in every adenoma cell, are small, measuring only 100-250 nm. Cells possessing a few larger granules (up to 450-500 $n m$ ). are rare or absent.

At present it is difficult if not impossible to assess the relative frequency of the two types of GHsecreting tumors, since no systematic studies of this kind have been undertaken. In previous studies, Lewis and Van Noorden (1972) have the largest collection of material (110 cases of acromegaly) examined by electron microscopy. Among the 110 adenomas only 23 "poorly granulated" tumors were found. Their published pictures, howaver, seemed to indicate that under the term "poorly granulated" adenoma, the authors referred to a partially degranulated form of densely granulated GH-cell adenoma and they did not describe tumors corresponding to our "sparsely granulated" GHcell tumor with fibrous bodies. In our relatively small collection of material the two classes showed a similar frequency.

It is even more difficult to estimate the incidence of fibrous bodies in $\mathrm{GH}$-secreting adenomas. They were first described by Cardell and Knighton (1966) in a case of acromegaly. Six years later Schochet et al. (1972), by means of light microscopy and a special staining method, detected three pituitary tumors with fibrous bodies out of 140 acidophil adenomas. Electron microscopy was performed only in the three positive cases. Since loosely built or small fibrous bodies, especially if they are not numerous, can easily be overlooked by light microscopy, several such tumors might have remained undetected in their series. In an ultrastructural analysis of $110 \mathrm{GH}$-secreting adenomas, Lewis and Van Noorden (1972) did not mention the existence of fibrous bodies.

Our collected material is not large enough to estimate the percentile occurrence of fibrous bodies. The fact, however, that they were detected in all sparsely granulated tumors and in two of the densely granulated ones, shows that they are not uncommon. Fibrous bodies were not detected in other types of pituitary adenomas and we assume that their occurrence indicates derivation of the tumor from $\mathrm{GH}$-cells.

\section{PROLACTIN-CELL ADENOMAS.}

\section{I. Densely granulated prolactin- cell adenoma (l case).}

The application of a specific and highly sensitive prolactinradioimmunoassay in recent years resulted in a rapidly growing interest in prolactin secreting tumors. It became possible to demonstrate elevated blood prolactin levels not only in cases of Forbes-Albright syndrome but also in an appreciable number of "clinically nonfunctioning"' chromophobe adenomas (Boyar et al., 1974; Tolis et al., 1974; Zimmerman et al., 1974). Prolactin secreting tumors are more common than was previously assumed and as many as 20-25 per cent of all pituitary adenomas might arise from prolactin cells.

The densely granulated prolactin cell tumor occurs infrequently and exhibits acidophilia by light microscopy. The secretory granules also stain by using Herlant's tetrachrome or Brookes' carmoisine techniques.

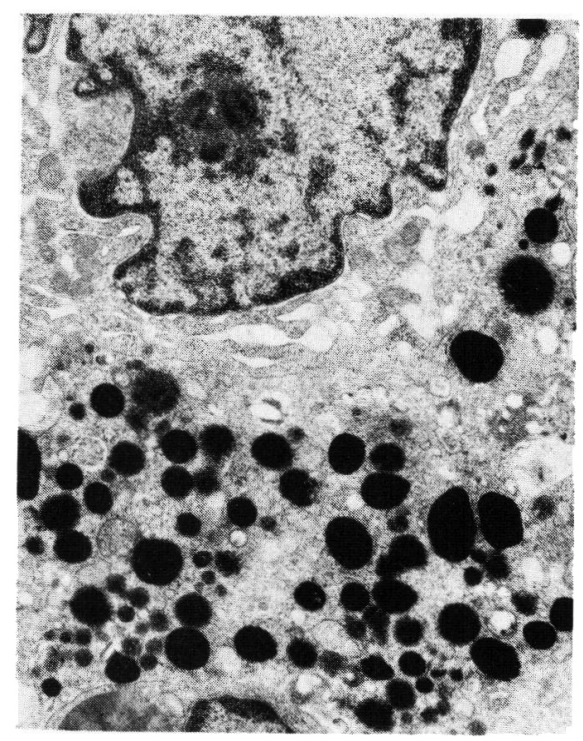

Figure 4-Densely granulated prolactin cell adenoma with secretory granules measuring up to $800 \mathrm{~nm}(\mathrm{x} \mathrm{14,500)}$ 
By electron microscopy, the cells of the densely granulated prolactin cell adenoma show a close resemblance to the normal resting prolactin cells of the non-tumorous pituitary (Fig. 4). The oval or oblong cells have an oval, or not uncommonly, pleomorphic nucleus. The parallel cisternae of the well developed RER are usually situated at the periphery of the cytoplasm. The Golgi apparatus is prominent, containing some dense immature pleomorphic secretory granules. The distinguishing marks of this tumor are the size and morphology of the secretory granules. They invariably exhibit high electron density and measure up to $1200 \mathrm{~nm}$ in diameter, averaging about $600 \mathrm{~nm}$ or over in diameter. Contrary to densely granulated GH-cells, many of the granules are oval or pleomorphic. Some pleomorphic granules, especially those near the Golgi region, have loosely fitted limiting membranes with an irregular lucent space between them and the electron dense core. The plasma membranes of the adenoma cells are closely apposed with occasional intercellular junctions (zonulae adherentes).

II. 2. Sparsely granulated prolactin cell adenoma with misplaced exocytosis (PAME) (9 cases).

This adenoma is not uncommon and may occur in association with galactorrhea-amenorrhea syndrome. Especially in male patients, it may behave as a "clinically nonfunctioning" chromophobe adenoma. The tumor appears to be "chromophobe" by conventional histologic stains. By applying Harlant's tetrachrome method or Brooke's carmoisine stain, small bright red secretory granules may be detected in some cells, usually only by using oil immersion lens. The immunoperoxidase technique, using specific antisera, may provide positive results (Zimmerman et al., 1974; Kovacs et al., 1975). The highly characteristic fine structural features of this adenoma have recently been described in detail (Horvath and Kovacs, 1974; Kovacs et al ., 1975), thus a concise summary of diagnostically important aspects will suffice here. The PAME is composed of closely apposed polyhedral cells with oval or pleomorphic nuclei (Fig. 5). The main cytoplasmic features are: 1) extensively developed RER, composed of several parallel rows of ribosome-studded cisternae, occupying large parts of the cytoplasm. Formation of Nebenkerns (concentric whorls of RER) is frequent and free ribosomes are usually numerous. 2) the prominent Golgi complex may occupy as much as one-third of the cytoplasmic area. Its sacculi are slightly or moderately dilated and regularly contain a variable number of dense immature secretory granules. 3) the dense spherical or pleomorphic secretory granules are not numerous and their longest diameter is only $130-500 \mathrm{~nm}$, averaging about $250 \mathrm{~nm}$. 4) extrusion of secretory granules on the lateral cell membranes into the intercellular space distant both from perivascular spaces and intercellular extensions of basement membrane, are readily observed (Fig. 6). This phenomenon was called misplaced exocytosis in previous studies (Horvath and Kovacs, 1974). The extruded granules have fuzzy outlines and are located in a membranous pit, formed by the fusion of cell membrane and the limiting membrane of the secretory granules.

The densely granulated prolactin cell adenoma, which appears to be uncommon, is easy to identify both by light and electron microscopy due to its close tinctorial and ultrastructural similarity to normal prolactin cells (Peake et al., 1969; Guinet et al., 1973). The cells of the "chromophobe" sparsely granulated PAME, however, are similar not to the normal resting prolactin cells of the non-tumorous pituitary, but to the stimulated prolactin cells seen in the non-tumorous or adenamatous hypophyses of oestrogen-treated animals (Lundin and Schelin, 1962; Schelin et al., 1964), as shown by electron microscopy.

Sparsely granulated cells answering the description of the cells of PAME have been detected in prolactin secreting "chromophobe" adenomas (Mirouze et al., 1969;
Racadot et al., 1971). Because of marked differences between these cells and normal prolactin cells, they were not identified as mammotrophs.

Previous authors (Fukumitsu, 1967; Kuromatsu, 1968; Foncin, 1971; Tomiyasu et as., 1973) dealing with the ultrastructure of "nonsecreting" chromophobe adenomas disclosed and documented some of the striking fine structural features of PAME without apparently linking them with prolactin cells.

We have found that the set of features described above are constant and characteristic in cases of sparsely granulated PAME making the electron microscopical diagnosis of this adenoma relatively easy as well as reliable.

\section{MIXED ADENOMAS COMPOSED OF GH AND PROLACTIN CELLS.}

(4 cases).

Somatotrophs and prolactin cells not only share cytoplasmic acidophilia, but they have ultrastructural similarities such as well developed lamellar RER, prominent Golgi apparatus and large electron dense secretory granules as well.

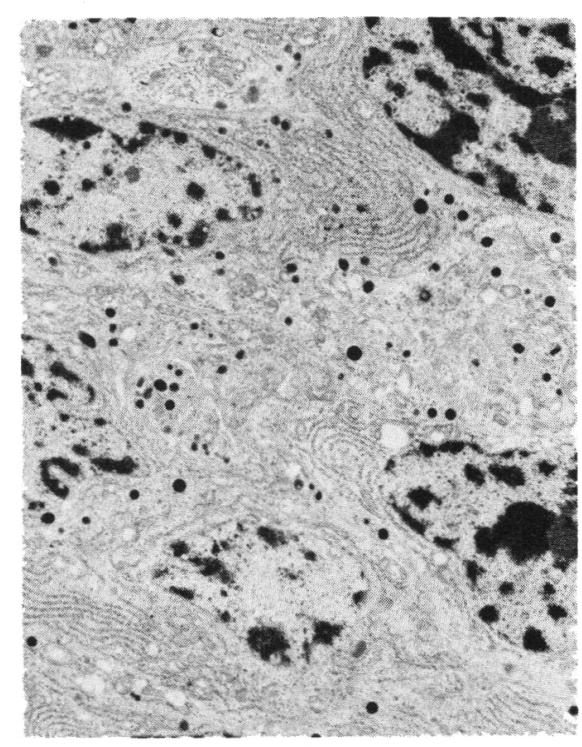

Figure 5-Sparsely granulated prolactin cell adenoma with misplaced exocytosis (PAME). Note the irregular nuclei, extensive RER, large Golgi areas and the small partly pleomorphic secretory granules (x 5,700) 
The molecular structures of the two hormones secreted by the two cell types are close to each other. In recent years it became evident that in some cases of acromegaly hyperse- cretion of $\mathrm{GH}$ is accompanied by hyperprolactinemia. This finding does not necessarily mean that a tumor is capable of secreting both hormones. Other pathologic proces-

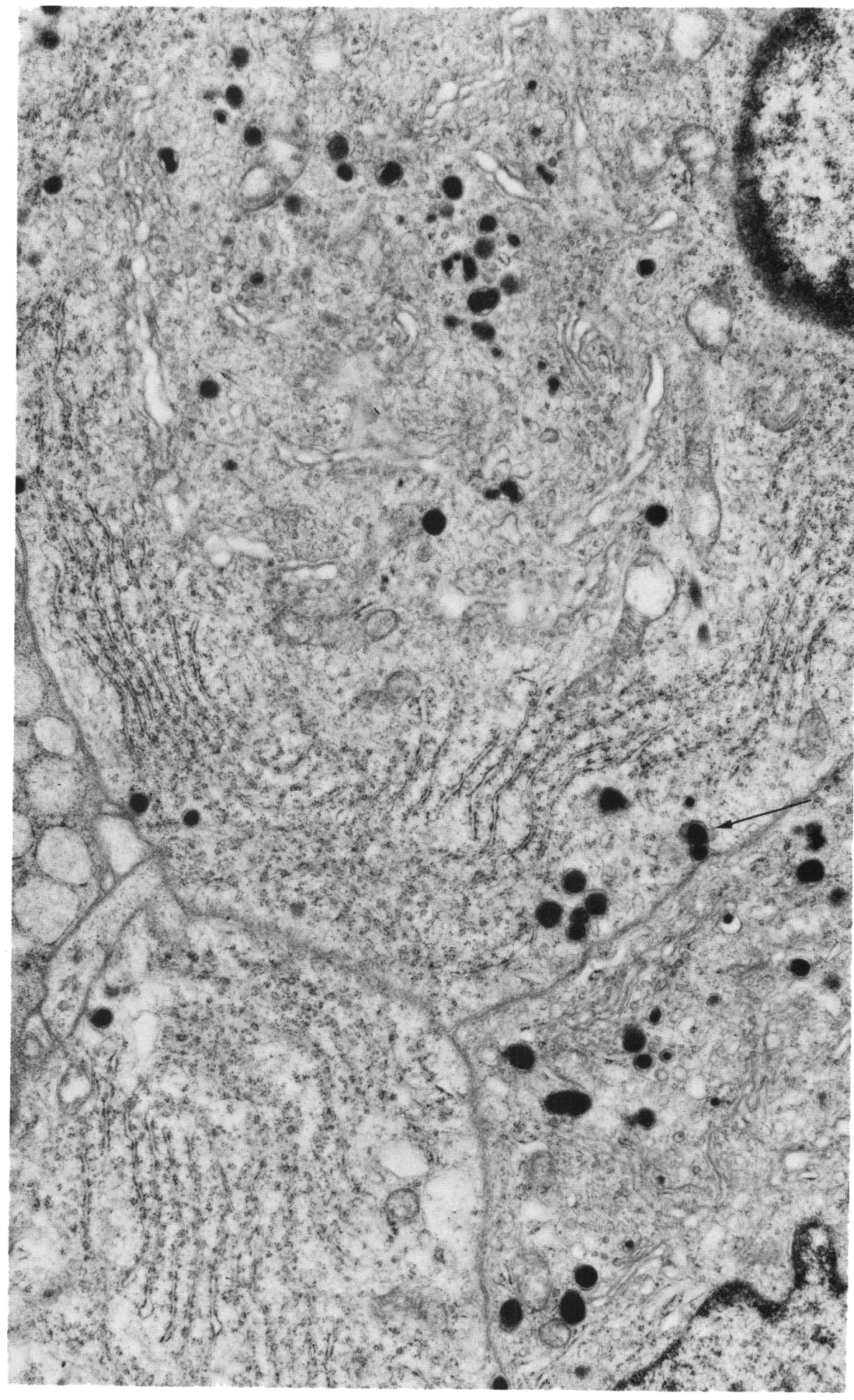

Figure 6-Portions of cells of a PAME exhibiting all characteristic features including misplaced exocytosis (arrow) (x 14,250) ses involving the stalk, median eminence and the hypophysiotropic area of the hypothalamus can interfere with the production, release and/or transport of prolactin inhibiting factor (PIF) and subsequently result in increased prolactin secretion from the non-tumorous gland (Tolis et al., 1974), provided that there is enough functioning adenohypophyseal tissue present. Ultrastructural analysis is the only reliable way to separate prolactin producing pituitary tumors from those associated with an enhanced prolactin production from the non-tumorous part of the gland.

The rare occurrence of pituitary adenomas composed of wellgranulated prolactin and $\mathrm{GH}$-cells has already been reported (Peillon et al., 1970; Guyda et al., 1973). The real incidence of this tumor type cannot be assessed with certainty at present. After having classified the sparsely granulated prolactin tumors with misplaced exocytosis (PAME) we analyzed our material for the presence of mixed tumors. In addition to a densely granulated GH-cell adenoma containing several densely granulated prolactin cells, we found four adenomas which were considered to represent mixed GHprolactin cell tumors. Light microscopically these adenomas contained groups of cells in which the secretory granules stained positively with Herlant's erythrosine and Brookes' carmoisine techniques. Ultrastructurally, in one tumor clinically associated with acromegaly, the GHcells were partly degranulated, whereas the prolactin cells were well granulated. In another case, the acromegaly was accompanied by a sparsely granulated GH-cell adenoma with fibrous bodies which contained several foci of densely granulated prolactin cells (Figs. 7 and 8 ). Two further adenomas were composed exclusively of foci of sparsely granulated GH-cells with fibrous bodies and of sparsely granulated prolactin cells with misplaced exocytosis. One of these cases had multiple endocrine adenomatosis (MEA) type I syndrome including acromegaly. The other patient was known to have a high prolactin level and exhibited some acromegaloid 


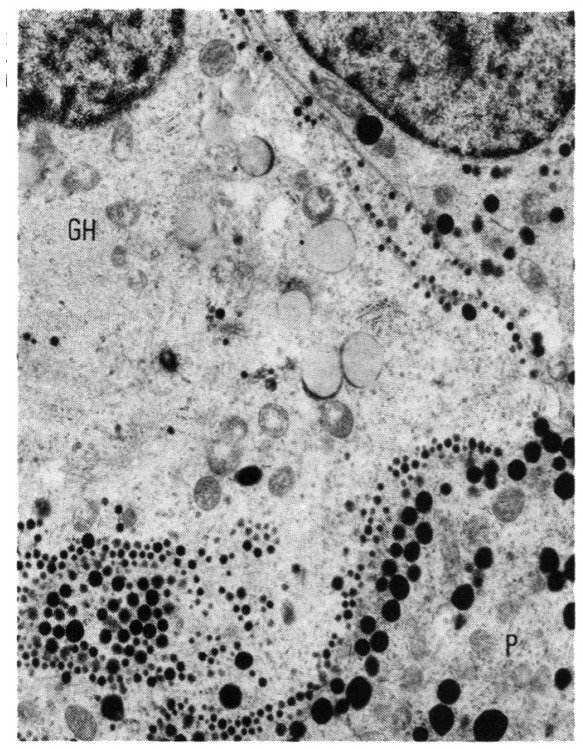

Figure 7-Detail of a mixed adenoma depicting a prolactin cell $(P)$ adjacent to sparsely granulated $\mathrm{GH}$-adenoma cells with a fibrous body $(\mathrm{GH})(\mathrm{x}$ 10,600 )

features. The ultrastructural characteristics of the $\mathrm{GH}$ or prolactin cells were identical with those already described under the corresponding headings. These findings indicate that every ultrastructural variant may occur in mixed $\mathrm{GH}$-prolactin cell adenomas, and in some cases an an intimate knowlege of various cell

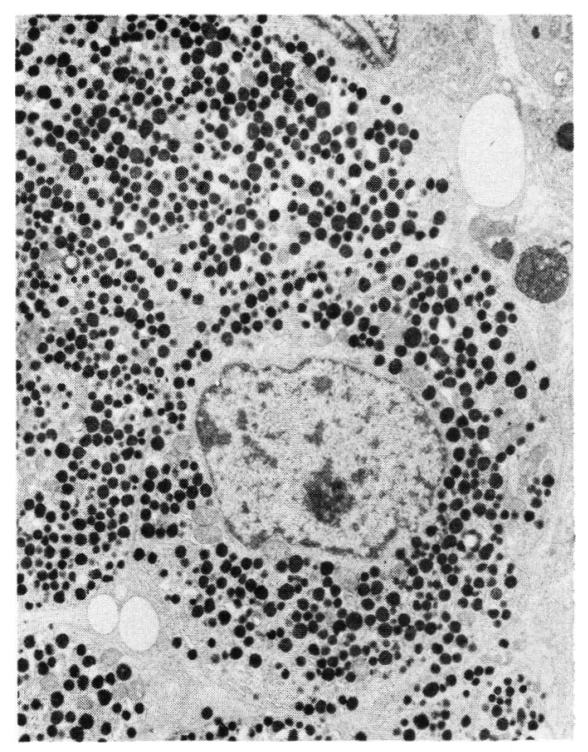

Figure 9-Densely granulated ACTHMSH producing adenoma from a case of Nelson's syndrome (x 5,500). types is indispensable in order to recognize these neoplasms. Our observations also suggest that the simultaneous occurrence of $\mathrm{GH}$ - and prolactin cells within the same neoplasm is not a matter of chance and the close relationship between the two cell types which was shown in animals (Schelin and Lundin, 1971) may exist in the human pituitary as well.

\section{MELANOCORTI- COTROPH (ACTH-MSH) CELL ADENOMAS.}

IV. I. Densely granulated ACTHMSH cell tumors (4 cases).

Adenomas arising from ACTH. MSH cells are associated either with hypercorticism or develop in patients who have been adrenalectomized because of pre-existing Cushing's syndrome (Nelson's syndrome) (Nelson et al., 1958). By light microscopy, the densely granulated form of the neoplasm exhibits well defined PAS-positivity distinguishing this type from all other pituitary adenomas. In addition to PASpositivity, the cytoplasmic granules may take up acid dyes as well, showing tinctorial properties similar to those of prolactin granules (Herlant and Pasteels, 1967), thus, ACTHMSH cells may behave as true amphophils.

Ultrastructurally many cells in these tumors show a close similarity to the ACTH-MSH cell of the nontumorous gland (Moriarty, 1973) (Fig. 9). The spherical, oval or angular cells have a round or slightly elongate nucleus and relatively dense cytoplasm. The RER is abundant in most cells, represented either by scattered short profiles or parallel stacks. A slight to moderate dilation of $E R$ is common. Both membrane bound and free ribosomes are usually numerous accounting mainly for the electron opacity of the cytoplasm. The prominent Golgi complex regularly contains a few immature secretory granules. All adenoma cells possess spherical or slightly "dented" secretory granules measuring $250-450$ $\mathrm{nm}$ in diameter. There may be considerable differences in the electron

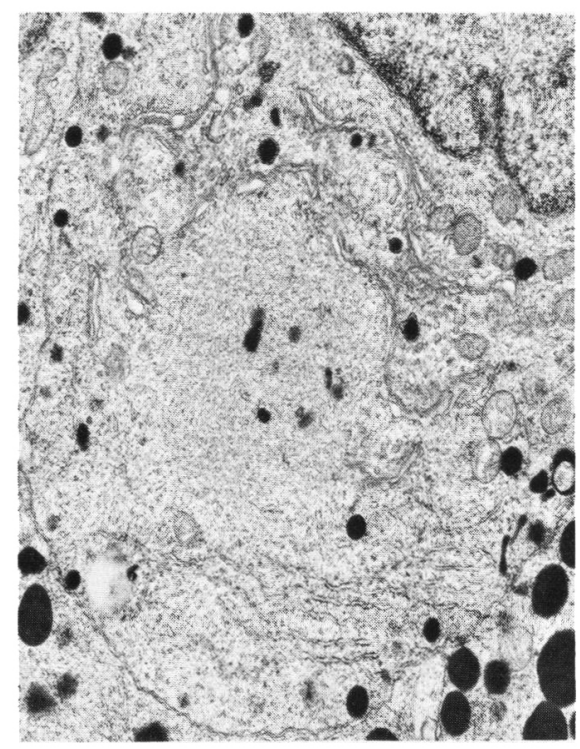

Figure 8-Electron micrograph of a mixed adenoma showing part of a prolactin cell next to a sparsely granulated GH-cell with fibrous body $(x 14,150)$.

density of secretory granules (Fig. 10 ). It is not clear whether or not these variations are attributable to different phases of maturation and/or secretion, or whether they indicate the presence of two separate granule populations. Partially degranulated cells containing smaller granules (av. $250 \mathrm{~nm}$ ) may occur.

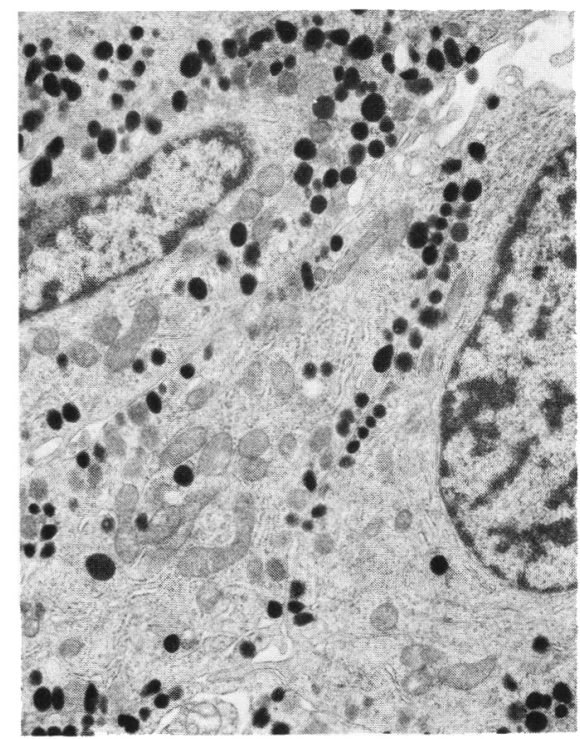

Figure 10-Same case as Figure 9. The adenoma cells contain well developed RER, numerous free ribosomes and secretory granules with strikingly different electron density $(x 11,450)$ 
Lining up of secretory granules along cell membranes is very common. Although granule extrusions were never observed. The mitochondria are generally not numerous, have moderately dense matrix and lamellar cristae. Some cells, however, showing different degrees of oncocytic transformation were encountered as well.

ACTH-MSH cell tumors developing in the presence of functioning adrenals are reported to contain a considerable amount of fine cytoplasmic microfilaments with an average diameter of $70 \AA$ (Racadot et al., 1973; Saeger et al., 1973b; Kovacs and Horvath, 1974) (Fig. 11). The size and electron microscopic appearance of this microfilamentous substance is identical with that of Crooke's hyalin found in the nontumorous ACTH-MSH cells of glucocorticoid-treated patients (DeCicco et al., 1972; Kovacs et al., 1974). On the other hand, it appears that ACTH-MSH secreting tumors developing in cases of Nelson's syndrome contain few or no microfilaments in the cytoplasm (Saeger, 1973b).

\section{2. Sparsely granulated $A C T H$ - MSH cell adenoma.}

On the basis of conventional histologic stains it was found that a considerable number of ACTHMSH cell tumors belong to the category of "chromophobe" adenomas (Nelson and Thorn, 1960; Rovit and Berry, 1965). Although the real incidence of chromophobe (or more correctly, sparsely granulated) adenomas might be lower than it was assumed earlier, their existence cannot be doubted. Sparsely granulated ACTH-MSH cell adenomas did not occur in our material, and in the literature available to us we found only one report dealing with the fine structure of such a neoplasm (Foncin, 1963). Detailed study of further cases is needed in order to achieve an appropriate classification of this tumor type.

Specific techniques, such as hormone radioimmunoassays, immunofluorescent and immunoperoxidase methods, as well as the ultrastructural study of pituitary tumors on a large scale are relatively recent procedures. Only a few cases have been studied with these sophisticated techniques and the available information is not sufficient to assess the incidence of ACTH-MSH secreting adenomas among all pituitary tumors. It also is not possible to determine the relative frequency of densely and sparsely granulated varieties occurring in association with Cushing's and Nelson's syndromes. It might be purely coincidental, but it is impressive that all four adenomas associated with Nelson's syndrome reported by Saeger (1973b) and two of our cases were well granulated.

A controversy related to the ACTH-secreting cells of the pituitary gland also should be elucidated here. When Farquhar (1957) first described the follicular cells in the rat pituitary, she suggested that these cells might be involved in corticotrophin production. Efforts to prove this hypothesis (Rennels, 1964; Yamashita, 1972) remained essentially fruitless. Bergland and Torack (1969) observed follicular structures in an ACTH-MSH tumor associated with Cushing's disease and considered this finding as evidence supporting the assumption that follicular cells are in fact producing ACTH in the human pituitary. In this laboratory it was recently shown (Horvath et al., 1974) that pituitary follicles are not permanent structures, and they are formed around ruptured granulated cells by different glandular cells undergoing marked cytological alterations. The participation in this process is not limited to a single cell type and GH cells, gonadotrophs as well as cells regarded as ACTH-MSH cells on the basis of specific immunoperoxidase technique (Moriarty, 1973), were seen to be involved in follicle formation. These structures do not seem to be related to hormone production in any way. It appears that the ability of pituitary granulated cells to form follicles is retained in the adenomatous cells as well. Follicles, occurring with variable frequency, were seen in various tumors, including ACTH-MSH cell adenomas (unpublished observations). Remarkably,

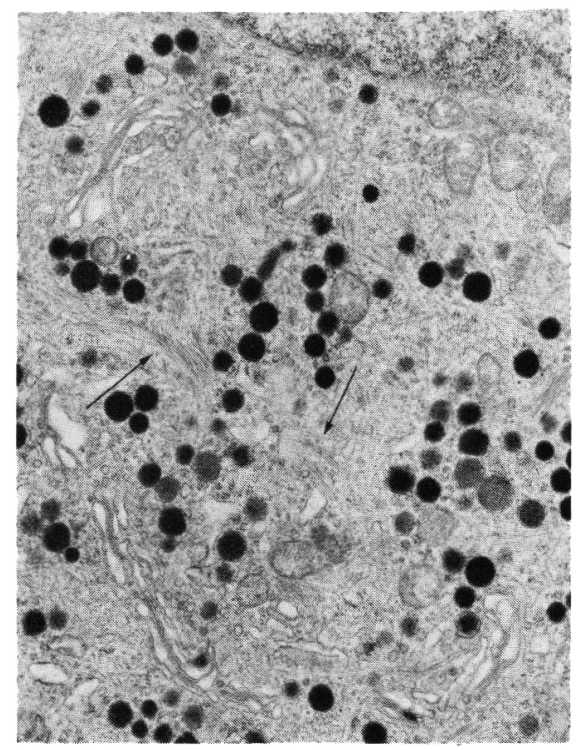

Figure 11-ACTH-MSH-cell adenoma from a case of hypercorticism. The prominent Golgi region contains secretory granules with varying electron opacity as well as bundles of type I microfilaments (arrows) $(x$ 17,500)

follicular cells in the adenomatous pituitary do not necessarily undergo those marked cytological changes seen in the non-tumorous pituitary.

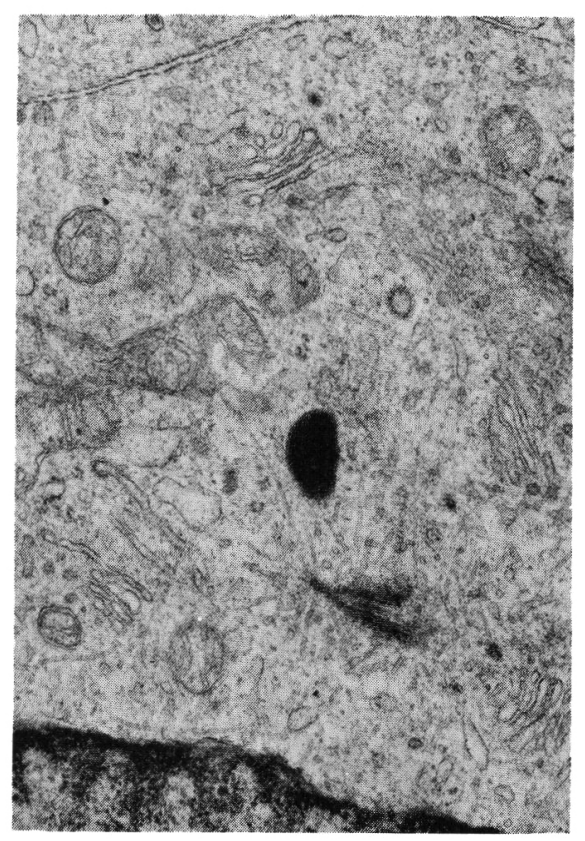

Figure 13-Golgi region of an undifferentiated adenoma cell lodging a centriole and numerous radially oriented as well as randomly scattered microtubules (x 23,500) 


\section{ADENOMAS COMPOSED OF UNDIFFERENTIATED CELLS.}

$V$. I. Undifferentiated cell adenomas ( 9 cases).

By light microscopy these tumors are chromophobic. A number of cells might exhibit varying degrees of cytoplasmic acidophilia due not to the presence of stainable secretory granules but to mitochondrial abundance commonly seen in this adenoma type. Clinically, no signs of hormonal hypersecretion are evident. Electron microscopy reveals the features of an undifferentiated adenoma, quite characteristic in a way. The relatively small polyhedral cells are closely apposed. The nuclei usually are strikingly irregular with multiple deep indentations. Mitotic figures may occur. The majority of cells have a scanty cytoplasm of low electron density containing short scattered profiles of poorly developed RER, clusters of free ribosomes and a modest number of small, dense, rod-shaped mitochondria (Fig. 12). Despite the relative scarcity of other cytoplasmic organelles, the crescent or ring-shaped Golgi complex is usually quite prominent. The sacculi, however, infrequently contain forming secretory granules. Cytoplasmic microtubules, situated mainly in the Golgi region, but also at other sites, are usually numerous in this adenoma type (Fig. 13). The secretory granules, found in every tumor cell, are small (100-250 $\mathrm{nm}$ in diameter) and uncharacteristic. Many of them have a clear halo between the dark core and the limiting membrane. Larger granules (up to $500 \mathrm{~nm}$ in diameter) occur occasionally. In the majority of cells the secretory granules line up along the cell membrane without any evidence of granule extrusions.

A marked increase in number and volume density of mitochondria, i.e. oncocytic transformation, is clearly evident in a varying proportion of cells in all of these tumors (Fig. 14).

In some of the undifferentiated cell adenomas, cells possessing well developed RER, in the form of parallel stacks heavily studded with ribosomes, can also be observed. Annu- late lamellae, a specially organized $E R$, not known in non-tumorous

cells of the human pituitary, were also seen in two undifferentiated

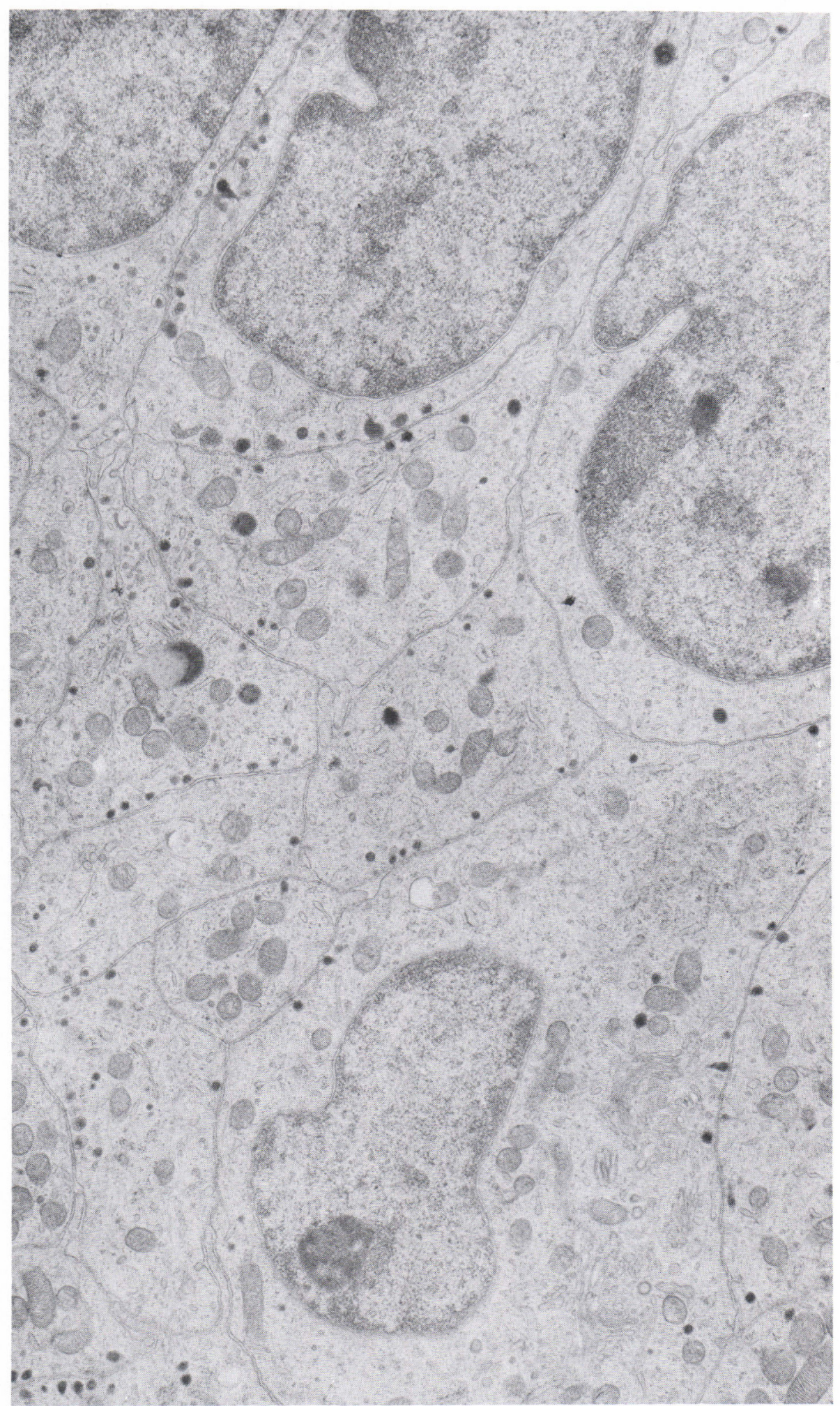

Figure 12-The typical appearance of an undifferentiated cell adenoma composed of cells with pleomorphic nuclei and light cytoplasm poor in organelles and secretory granules $(\mathrm{x} 11,700)$ 


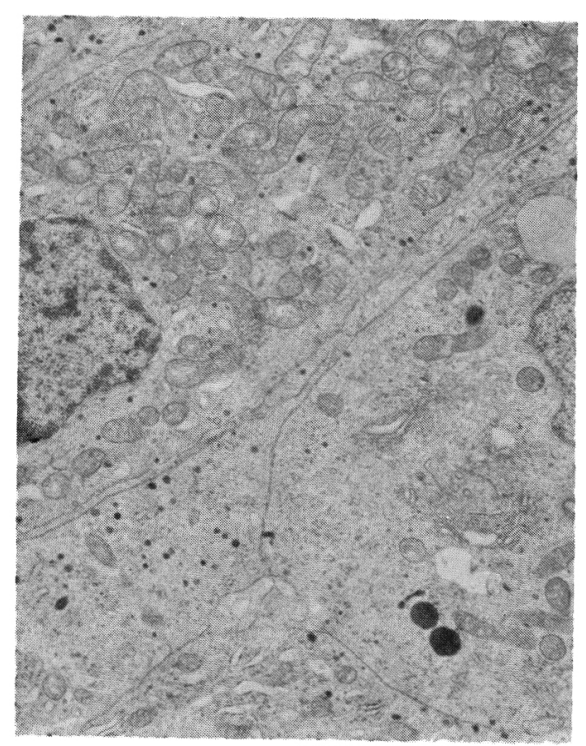

Figure 14-Field from an undifferentiated cell adenoma showing a cell in a phase of advanced oncocytic transformation $(x 9,600)$

adenomas (Kovacs et al., in press) (Fig. 15). Unusually long intercellular junctions (zonulae adherentes) are found frequently in this tumor type.

\section{2. Oncocytoma (5 cases).}

By light microscopy, these adenomas are either chromophobe or they show cytoplasmic acidophilia. The intensity of

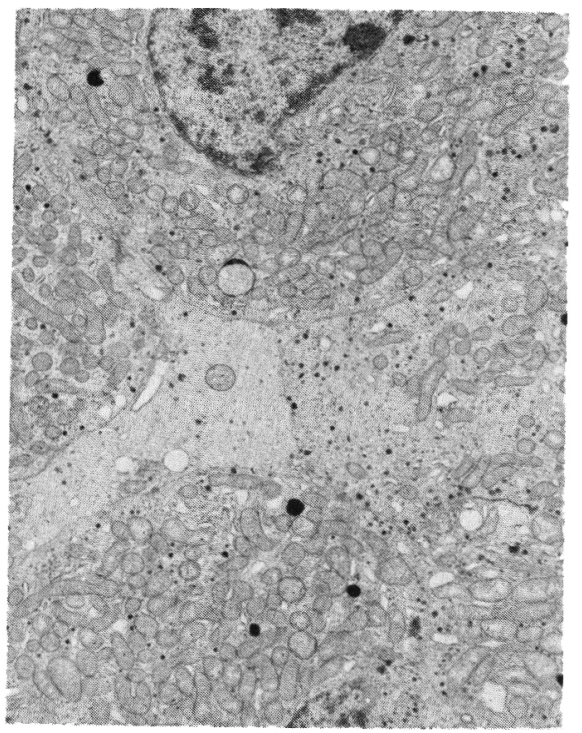

Figure 16-Portions of several cells of a pituitary oncocytoma $(x 7,200)$ acidophil coloration appears to depend on the proportion of "dark" and "light" oncocytes in the tumor. Clinically, none of the five tumors were associated with any sign of hormonal hypersecretion. Electron microscopy revealed that the cells of this tumor are larger than those of the non-tumorous pituitary, but much smaller than the oncocytes of other glands such as Hürthle cells, salivary gland oncocytes or even the oxyphils of parathyroids. This fact might explain why this tumor has never been recognized by light microscopy. Ultrastructurally, the irregular, indented nuclei have the same appearance as those of undifferentiated cell adenomas. The cytoplasm is almost filled with closely packed mitochondria (Fig. 16). These organelles are rod-shaped with fine granular matrix and closely spaced lamellar cristae in the "dark" oncocytes and are spherulated with cavitations and loss of cristae in the "light" oncocytes (Fig. 17). Signs indicating mitochondrial division are occasionally apparent. The scanty RER is represented by a few scattered short profiles. Free ribosomes are present among the mitochondria. The Golgi complex is well recognizable and it may even be prominent in some cells. Cytoplasmic microtubules are seen frequently in and around the Golgi region. The secretory granules are small (100-250 nm in diameter), but are consistently present in every oncocyte.

Oncocytomas may contain cells which can be considered transitory forms between cells possessing normal amounts of mitochondria and oncocytes. The fine structural appearances of these cells are identical with those seen in the cells undergoing oncocytic transformation in undifferentiated cell adenomas.

Undifferentiated cell adenomas account for approximately 20 per cent of all adenomas in our material. The fine structural features are well known and well documented under the term of chromophobe adenomas (Schelin, 1962; Fukumitsu, 1967; Kuromatsu, 1968; Zambrano et al., 1968, Schechter, 1973a; Tomiyasu et al., 1973; Lewis and Van Noorden,

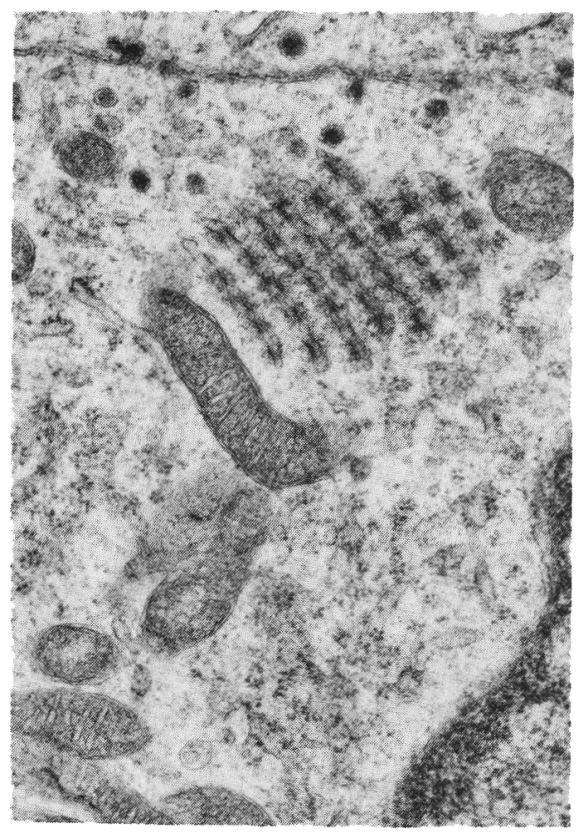

Figure 15-Annulate lamellae in an undifferentiated adenoma cell $(x 23,500)$

1974), usually along with well recognizable examples of PAME, the other frequently occurring "chromophobe" adenoma. Notwithstanding their distinguishable features, undifferentiated cell adenomas and sparsely granulated prolactin cell tumors have not previously been clearly separated. It is known that undifferentiated cell tumors might result in hyperprolac-

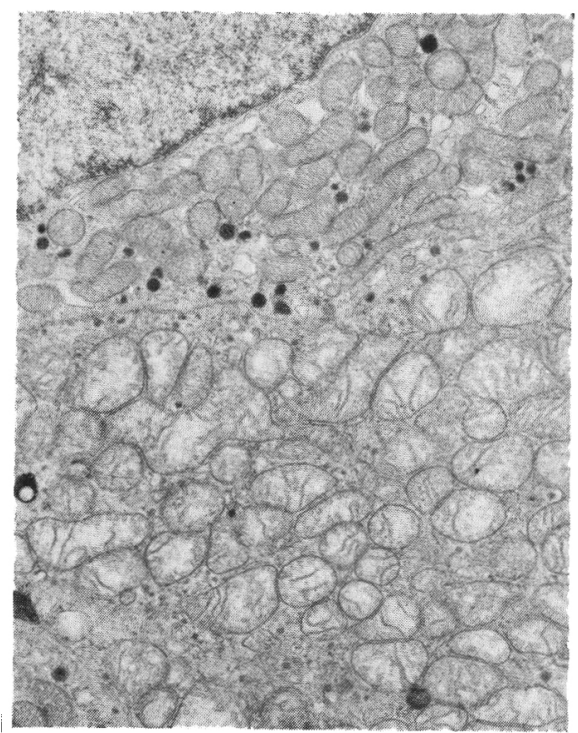

Figure 17-."Dark" and "light" oncocytes from a pituitary oncocytoma ( $\mathrm{x}$ $14,000)$ 
tinemia by interfering with the release of PIF, most probably due to suprasellar extentions of the tumor and involvement of hypothalamus (Tolis et al ., 1974). Thus, distinction between these adenomas has theoretical as well as clinical significance. At present only fine structural analysis can help to elucidate the nature of the tumor and the possible source of prolactin.

Because of lack of characteristic cytoplasmic features, undifferentiated cell adenomas cannot be linked to any known pituitary cell type. It is readily evident, however, that the present classification covers the adenomas arising from $\mathrm{GH}$, prolactin and ACTH-MSH cells but does not include tumors originating from the so-called "mucoid" cell series secreting FSH, LH or TSH. The existence of such tumors was doubtful earlier. There is some recent data, however, indicating that pituitary tumors producing gonadotroph hormones or thyrotrophin do occur (Hamilton et al., 1970; Woolf and Schenk, 1974). The fine structure of such neoplasms, to our knowledge, has not as yet been reported, but it would not be surprising to find them belonging to Class V. Scattered cells exhibiting a higher degree of cytoplasmic differentiation in undifferentiated cell tumors resemble either $\mathrm{LH}$ or TSH-cells of the nontumorous pituitary. In addition, in two of our undifferentiated cell tumors we observed markedly hypertrophied ring-shaped Golgi complexes which are most likely to be found in the castration cells (hypertrophied FSH gonadotrophs) of the pituitary of gonadectomized subjects. The molecular structure of the hormones secreted by the pituitary basophils are most closely related as well. The A-chains are identical in their molecules and there are differences only in their B-chains (Moriarty, 1973). Thus, it is reasonable to assume the existence of a common precursor of pituitary "mucoid" or basophil cells which might give rise to the undifferentiated cell adenomas. This suggestion, however, can be substantiated or disproved only by detailed clini- cal, biochemical and ultrastructural studies of several such cases.

Pituitary oncocytomas are not exceedingly rare although they have not been described until recently (Kovacs and Horvath, 1973; Landolt and Oswald, 1973). Oncocytic transformation of hypophyseal glandular cells occurs frequently in nontumorous as well as in adenomatous pituitaries (Kinnman, 1973; Kovacs et al., 1974a). We found that pituitary cells, as in Hürthle cells, parathyroid oxyphil cells or salivary gland duct epithelium, do retain some fine structural characteristics even in advanced phases of oncocytic transformation, which renders it possible to link them with their cellular source. The cells of the pituitary oncocytomas examined so far showed features (nuclear morphology, granule size, distribution and morphology, abundance of microtubules, etc.) shared by the undifferentiated cell adenomas. Intermediary cells, being in different stages of oncocytic transformation in these two adenomas, are indistinguishable from each other. Thus, it appears that many, if not all, pituitary oncocytomas represent an extreme form of oncocytic transformation usually evident in undifferentiated cell adenomas.

Recently, Schochet et al. (1974) put forward the hypothesis that salivary gland rests, present in the posterior lobe, might give rise to pituitary oncocytomas. The development of tumors of such origin cannot be excluded. We wish to point out, however, that the oncocytic tumors observed by us (Kovacs and Horvath, 1973), as well as by Landolt and Oswald (1973), appeared to be of adenohypophyseal origin with typical secretory granules and not showing glandular arrangement of cells and the typical intercellular junctional complexes (terminal bars) characteristic of salivary gland structures which should be retained in salivary gland tumors.

\section{DISCUSSION}

This electron microscopic classification has already proved useful in identification of pituitary adenomas, a goal that often cannot be achieved by means of light microscopy. The proposed system, based on present knowledge in this field, is an open one permitting future changes if hitherto unknown entities (e.g. FSH, LH or TSH producing tumors) should be disclosed.

This classification is not suitable to assess the possible malignant nature of certain tumors and obviously cannot be used to follow-up therapeutic effects. On the other hand, proper identification of adenohypophyseal neoplasms will help to elucidate several yet unanswered questions. A greater collection of material will enable us to determine the incidence of various pituitary adenomas, as well as to evaluate the effect of various factors such as sex, age and hormonal influences on their occurrence. Systematic fine structural studies will also clarify the relationship between the densely and sparsely granulated forms of adenomas. At present we do not have enough data to provide a definite answer to the questions: a) do these variants transform into each other? $b$ ) is the transformation reversible? c) are there qualitative differences between densely and sparsely granulated adenomas and if so, what is their significance? Another important question is the relationship between fine structure and functional activity. At present we only know that both densely and sparsely granulated tumors may be associated with high or low secretory activity clinically. Thus, granularity of a tumor per se is obviously not a reliable indicator of hormonal activity. Careful and critical selection of more criteria and thorough investigation of further clearly identified cases will be necessary to establish the relationship between the fine structure and hormonal activity of pituitary adenomas.

It has long been known that certain adenohypophyseal tumors exhibit a faster rate of growth than others. Some of them show a tendency to recur as well. At present it is impossible to predict the probably behaviour of any pituitary neoplasm. The identification of these tumors, based on well defined criteria, and 
follow-up of cases for a longer period of time (10-15 years) will render it possible to determine whether or not some characteristics, such as higher growth rate, recurrence, etc. are linked to certain types of adenomas or rather represent individual variations.

\section{ACKNOWLEDGEMENTS}

Dr. H. P. Higgins, Di. W. Singer (Dept. of Medicine), Dr. W. J. Horsey, Dr. A. R. Hudson (Dept. of Neurosurgery), Dr. T. D. R. Briant (Dept. of Otolaryngology) and Dr. J. M. Bilbao (Dept. of Pathology), St. Michael's Hospital; Dr. B. Rewcastle (Dept. of Neuropathology) and Dr. C. Ezrin (Dept. of Medicine), Toronto General Hospital; Dr. B. Cruickshank, Dr. N. A. Kerenyi (Dept. of Pathology) and Dr. R. H. Sheppard (Dept. of Medicine), Sunnybrook Medical Centre, cooperated in providing the material for this study. We wish to acknowledge their contribution with thanks. We are grateful to Mrs. Gezina Ilse for the technical assistance and to Mrs. Maureen Rowling for the secretarial help.

\section{REFERENCES}

BERGLAND, R. M., and TORACK, R. M. (1969). An ultrastructural study of follicular cells in the human pituitary. American Journal of Pathology, 57, 273-297.

BOYAR, R. M., KAPEN, S., FINKELSTEIN, J. W., PERLOW, M., SASSIN, J. G., FUKUSHIMA, D. K., WEITZMAN, E. D., and HELLMAN, L. (1974). Hypothalamic-pituitary function in diverse hyperprolactinemic states. Journal of Clinical Investigation, 53, 1588-1598.

CARDELL, R. R., Jr., and KNIGHTON, R. S. (1966). The cytology of a human pituitary tumor: an electron microscopic study. Transactions of the American Microscopical Society, 85, 58-78.

DeCICCO, F. A., DEKKER, A., and YUNIS, E. J. (1972). Fine structure of Crooke's hyaline change in the human pituitary gland. Archives of Pathology, 94, 65-70.

DONIACH, I. (1972). Cytology of pituitary adenomas. Journal of Royal College of Physicians of London, 6, 299-308.

FARQUHAR, M. G. (1957). "Corticotrophs" of the rat adenohypophysis as revealed by electron microscopy. Anatomical Records, 127, 291 (abstr).

FONCIN, J. F. (1971). Morphologie ultrastructurale de l'hypophyse humaine. Neuro-Chirurgie, 17, Suppl. 1, 10-24.

FONCIN, J. F., and LE BEAU, J. (1963). Étude au microscopie optique et électronique d'une tumeur hypophysaire à fonction adrénocorticotrope. Comptes rendus de la Societé de Biologie, 157, 249-252.

FUKUMITSU, T. (1967). Electron microscopic study of the human pituitary adenomas. Archiv für Japanische Chirurgie, 33, 329-349.

GUINET, P., GIROD, C., POUSSET, G., TROUILLAS, J., and L'HERMITE, $M$. (1973). Un cas d'adénome à cellules à prolactine: dosage de prolactine, étude au microscope électronique, resultats post-opératoires. Annales d'Endocrinologie, 34, 407-417.

GUYDA, H., ROBERT, F., COLLE, E., and HARDY, J. (1973). Histologic, ultrastructural and hormonal characterization of a pituitary tumor secreting both hGH and prolactin. Journal of Clinical Endocrinology and Metabolism, 36, 531-547.

HAMILTON, C. R., Jr., ADAMS, L. C., and MALOOF, F. (1970). Hyperthyroidism due to thyrotropin-producing pituitary chromophobe adenoma. New England Journal of Medicine, 283, 1077-1080.

HERLANT, M. and PASTEELS, J. L. (1967). Histophysiology of human anterior pituitary. Methods and achievements in experimental pathology, Vol. 3, 250-305, Ed. E. Bajusz and G. Jasmin. S. Karger, Basel/New York

HORVATH, E., and KOVACS, K. (1974). Misplaced exocytosis. Distinct ultrastructural feature in some pituitary adenomas. Archives of Pathology, 97, 221-224.

HORVATH, E., KOVACS, K., PENZ, G., and EZRIN, C. (1974). Origin, possible function and fate of "follicular cells" in the anterior lobe of the human pituitary. American Journal of Pathology, 77, 199-212.

KINNMAN, J. (1973). Acromegaly. An ultrastructural analysis of 51 adenomas and a clinical study in 80 patients treated by transanthrosphenoidal operation. P. A. Norstedt \& Söner, Stockholm.

KOVACS, K., and HORVATH, E. (1973). Pituitary "chromophobe" adenoma composed of oncocytes. Archives of Pathology, 95, 235-239.

KOVACS, K., and HORVATH, E. (1974). Amphophil adenoma of the human pituitary gland with masses of cytoplasmic microfilaments. Endokrinologie, 63, 402-408.

KOVACS, K., HORVATH, E., and BILBAO, J. M. (1974a). Oncocytes in the anterior lobe of the human pituitary gland. A light and electron microscopic study. Acta Neuropathologica (Berlin), 27, 43-53.

KOVACS, K., HORVATH, E., and BILBAO, J. M. (in press). Annulate lamellae in adenomas of human pituitary glands. Acta anatomica.

KOVACS, K., HORVATH, E., CORENBLUM, B., SIREK, A. M. T., PENZ, G., and EZRIN, C. (1975). Pituitary chromophobe adenomas consisting of prolactin cells: a histologic, immunocytological and electron microscopic study. Virchows Archiv Abteilung A Pathologische Anatomie, 366, 113-123.

KOVACS, K., HORVATH, E., STRATMAN, I. E. and EZRIN, C. (1974b). Cytoplasmic microfilaments in the anterior lobe of the human pituitary gland. Acta anatomica, 87, 414-426.
KUROMATSU, C. (1968). The fine structure of the human pituitary chromophobe adenoma with special reference to the classification of this tumor. Archivum Histologicum Japonicum, 29, 41-61.

LANDOLT, A. M., and OSWALD, U. W. (1973). Histology and ultrastructure of an oncocytic adenoma of the human pituitary. Cancer, 31, 1099-1105.

LEWIS, P. D., and VAN NOORDEN, S. (1972). Pituitary abnormalities in acromegaly. Archives of Pathology, 94, 119-126.

LEWIS, P. D., and VAN NOORDEN, S. (1974). "Nonfunctioning" pituitary tumors. Archives of Pathology, 97, 178-182.

LUNDIN, M., and SCHELIN, U. (1962). Light and electron microscopical studies on the pituitary in stilboestrol-treated rats. Acta pathologica et microbiologica Scandinavica, 54, 66-74.

McCORMICK, W. F., and HALMI, N. S. (1971). Absence of chromophobe adenomas from a large series of pituitary tumors. Archives of Pathology, 92, 231-238.

MILHAUD, M., and PAPPAS, G. D. (1968). Cilia formation in the adult cat brain after pargyline treatment. Journal of Cell Biology, 37, 599-609.

MIROUZE, J., JAFFIOL, C., MARY, P., BALDET, P. and MONNIER, L. (1969). Deux syndromes originaux "Amenorrhéegalactorrhée" par tumeur hypophysaire. Discussion anatomoclinique. Etude ultrastructurale de l'un d'eux. Annales d'Endocrinologie, 30, 810-821.

MORIARTY, G. C. (1973). Adenohypophysis: ultrastructural cytochemistry. A review. Journal of Histochemistry and Cytochemistry, 21, 855-894.

MOSCA, L., and VASSALLO, G. (1970). Morphologia dei tumori ipofisari nell'huomo. Atti del XIIl Congresso Nationale della Società Italiana di Endocrinologia. 13, 339-401.

NELSON, D. H., MEAKIN, J. W., DEALY, J. B., Jr., MATSON, D. D., EMERSON, K., Jr., and THORN, G. W. (1958). ACTH-producing tumor of the pituitary gland. New England Journal of Medicine, 259, 161-164.

NELSON, D. H., and THORN, G. W. (1960). ACTH-producing tumors following adrenalectomy for Cushing's syndrome. Annals of Internal Medicine, 52, 560-569.

PEAKE, G. T., McKEEL, D. W., JARETT, L., and DAUGHADAY, W. H. (1969). Ultrastructural, histologic and hormonal characterization of a prolactin-rich human pituitary tumor. Journal of Clinical Endocrinology and Metabolism, 29, 1383-1393.

PEILLON, F., VILA-PORCILE, E., OLIVIER, L., and RACADOT, J. (1970). L'action des oestrogènes sur les adénome hypophysaires chez l'homme. Annales d'Endocrinologie, 31, 259-270.

PELlETIER, G. (1971). Classification et physiopathologie des tumeurs hypophysaires. L'Union Médical du Canada, 100, 1779-1783. 
POLYZONIS, M. G. (1970). Ultrastructural study of human parathyroid adenoma and the occurrence of abnormal cilia in the adenoma cells. Pathologia Europaea, 5, 454-469.

RACADOT, J., PEILLON, F., VILAPORCILE, E., and OLIVIER, L. (1973). Les adénomes hypophysaires dans la maladie de Cushing. Étude de 21 cas. Annales d'Endocrinologie, 34, 753-754.

RACADOT, J., VILA-PORCILE, E., PEILLON, F., and OLIVIER, L. (1971). Adénomes hypophysaires à cellules à prolactine: étude structurale et ultrastructurale correlations anatomo-cliniques. Annales d'Endocrinologie, 32, 298-305.

RENNELS, E. G. (1964). Electron microscopic alterations in the rat hypophysis after scalding. American Journal of Anatomy, 114, 71-91.

ROBERT, F. (1973). L'adénome hypophysaire dans l'acromégalie-gigantisme. Étude macroscopique, histologique et ultrastructurale. Neuro-Chirurgie, 19, Suppl . 2, 117-184.

ROVIT, R. L., and BERRY, R. (1965). Cushing's syndrome and the hypophysis. A re-evaluation of pituitary tumors and hyperadrenalism. Journal of Neurosurgery, 23, 270-292.

SAEGER, W. (1973a). Licht- und elektronenoptische Untersuchungen zur sekretorischen Aktivität von Hypophysenadenomen bei Akromegalie. Virchows Archiv Abteilung A Pathologische Anatomie, 358, 343-354.
SAEGER, W. (1973b). Zur Ultrastruktur der Hypophysenadenome beim CushingSyndrom nach Adrenalektomie. Virchows Archiv Abteilung A Pathologische Anatomie, 361, 39-50.

SCHECHTER, J. (1973a). Electron microscopic studies of human pituitary tumors. I. Chromophobic adenomas. American Journal of Anatomy, 138, 371-386.

SCHECHTER, J. (1973b). Electron microscopic studies of human pituitary tumors. II. Acidophilic adenomas. American Journal of Anatomy, 138, 387-399.

SCHELIN, U. (1962). Chromophobe and acidophil adenomas of the human pituitary gland. A light and electron microscopic study. Acta pathologica et microbiologica Scandinavica, Suppl. 158, 5-80.

SCHELIN, U., and LUNDIN, P. M. (1971). An electron microscopic study of normal and neoplastic acidophil cells of the rat pituitary. Acta Endocrinologica (Kbh), 67, 29-39.

SCHELIN, U., LUNDIN, P. M., and BARTHOLDSON, L. (1964). Light and electron microscopic studies on an autonomous stilboestrol-induced pituitary tumor in rats. Endocrinology, 75, 893-900.

SCHOCHET, S. S., Jr., McCORMICK, W. F, and HALMI, N. S. (1972). Acidophil adenomas with intracytoplasmic filamentous aggregates. A light and electron microscopic study. Archives of Pathology, 94, 16-22.
SCHOCHET, S. S., Jr., McCormick, W. F., and HALMI, N. S. (1974). Salivary gland rests in the human pituitary. Light and electron microscopical study. Archives of Pathology, 98, 193-200.

TOLIS, G., SOMMA, M., CAMPENHOUT, J. Van, and FRIESEN, H. (1974). Prolactin secretion in sixty-five patients with galactorrhea. American Journal of Obstetrics and Gynecology, 118, 91-101.

TOMIYASU, U., HIRANO, A., and ZIMMERMAN, H. M. (1973). Fine st ructure of human pituitary adenoma. Archives of Pathology, 95, 287-292.

WOOLF, P. D., and SCHENK, E. A. (1974). An FSH-producing pituitary tumor in a patient with hypogonadism. Journal of Clinical Endrocrinology and Metabolism, 38, 561-568.

YAMASHITA, K. (1972). Fine structure of the mouse anterior pituitary maintained in a a short-term incubation system. Zeitschrift für Zellforschung, 124, 465-478.

ZAMBRANO, D. AMEZUA, L. DICKMANN, G., and FRANKE, E. (1968). Ultrastructure of human pituitary adenomata. Acta Neurochirurgica, 18, 78-94.

ZIMMERMAN, E. A., DEFENDINI, R., and FRANTZ, A. G. (1974). Prolactin and growth hormone in patients with pituitary adenomas: a correlative study of hormone in tumor and plasma by immunoperoxidase technique and radio-immunoassay. Journal of Clinical Endocrinology and Metabolism, $38,577-584$. 